\title{
ICT Teachers' Professional Growth Viewed in terms of Perceptions about Teaching and Competencies
}

\author{
Recep Cakir \\ Amasya University, \\ Amasya, Turkey \\ recepcakir@gmail.com
}

\author{
Soner Yildirim \\ Middle East Technical \\ University, Ankara, Turkey
}

soner@metu.edu.tr

\section{Executive Summary}

Technology integration into the classroom has a major role in creating rich learning and teaching environments. It is obvious that the success of the effective use of technology in classrooms highly depends on Information and Communication Technology (ICT) teachers who are responsible for integrating technology and mentoring other teachers in using it successfully. However, it is unclear how ICT teachers play a role for the achievement of the integration process and what challenges they experience during this process. The purpose of this study is, therefore, to portray the professional growth of ICT teachers in terms of their perceptions of teaching and their competencies in the Turkish elementary education system. Data was obtained from 104 (55 female, 49 male) ICT teachers. The quantitative data analysis was supplemented with a qualitative analysis to get a better understanding of the professional growth among in-service ICT teachers. Results showed that despite their positive self-perceptions of competence, ICT teachers faced difficulties such as classroom management, number of students, and hardware-software issues regarding the effective use of technology, especially cutting edge technology, in the classroom. According to teachers, the ability to integrate technology in the classroom was negatively affected by time limitations, poor design of Information Technology (IT) class, lack of flexibility in their roles as teachers, overcrowded classes, and classroom management issues. Finally, this study looked at ICT teachers' opinions regarding factors that encourage/discourage them from working in schools. The results of this study also shed light on the awareness of the significance of integrating technology into their teaching and learning activities.

Keywords: ICT teaching; professional growth; perception of teaching; pedagogical and subject matter competencies.

Material published as part of this publication, either on-line or in print, is copyrighted by the Informing Science Institute. Permission to make digital or paper copy of part or all of these works for personal or classroom use is granted without fee provided that the copies are not made or distributed for profit or commercial advantage AND that copies 1) bear this notice in full and 2) give the full citation on the first page. It is permissible to abstract these works so long as credit is given. To copy in all other cases or to republish or to post on a server or to redistribute to lists requires specific permission and payment of a fee. Contact Publisher@InformingScience.org to request redistribution permission.

\section{Introduction}

Studies about technology and education report that technology, when used appropriately, can greatly enhance educational productivity in terms of achievement, learning styles, attitudes, cooperative work, and ability to access information (Clements \& Sarama, 2003; Hew \& Brush, 2007; Kulik, 2002; Yildirim, 
2007). Moreover, studies of technology-rich environments indicate that the general effects of technology on student motivation and attitudes towards learning may be greater than previously thought (Hainey, Connolly, Stansfield, \& Boyle, 2011; Kulik, 2002). While the availability of new technologies such as the Internet and web technologies are clearly having an effect on teaching and learning activities, the use of technology and its integration into the processes of education is dependent upon the use of this technology by the teacher. Studies emphasize that the teacher is the central figure in decisions as to whether or not to use technology, since its integration into the classroom is affected by teacher's attitudes, perceptions, and technical knowledge (Angeli \& Valanides, 2009; Mishra \& Koehler, 2006; Rohaan, Taconis, Wim \& Jochems, 2010). Despite this, some studies show that although technology is available in the classrooms, teachers do not use technology effectively in their instructional purposes (Ertmer, 2005; Hew \& Brush, 2007; Yildirim, 2007).

Today's schools require teachers to possess a repertoire of effective teaching strategies to meet the needs of all their students. A teacher's repertoire consists of all the various teaching approaches and strategies he or she uses to facilitate effective learning by students. Arends (2001) notes that effective teaching requires careful and reflective thought about what the teacher is doing and the effects of his or her accomplishments on student social and academic learning. Employing a teaching strategy that has a solid theoretical basis will make the computer a more effective teaching tool (Donnelly, McGarr, \& O'Reilly, 2011; Ertmer, 2005; Hew \& Brush, 2007). This is supported by Mishra and Koehler (2006) with the explanation of three aspects of knowledge as technological, pedagogical, and content knowledge, and the need for teachers to integrate subject-matter knowledge with both technological and pedagogical expertise for a successful teaching career. Effective teaching is not based on who a teacher is, but on what a teacher does in terms of preparation and applying plans into the teaching-learning environment (König, Blömeke, Paine, Schmidt, \& Hsieh, 2011; Minor, Onwuegbuzie, Witcher, \& James, 2002).

In Turkey, it is the Information and Communication Technology (ICT) teachers who are not only primarily responsible for integrating technology into K-8 classrooms (kindergarten to 8th grade classes), but also for informally mentoring other teachers to use technology.

As computers have become an important part of our lives, schools have made concerted efforts to provide students with instruction that allows them to use computers from an early age. All over the world, the use of technology in education has become more common with the increasing investments of the countries in educational technology. For example, Turkey makes huge investments in educational technology to conduct comprehensive projects to increase the use of technology in teaching and learning activities. With the aim of improving the quality of education in the country, 7100 ICT classes in 5800 schools were equipped with computers, projection, and multimedia devices (MoNE, 2012). In this regard, ICT teachers play an important role in the smooth integration of technology into the classroom in Turkey and in the achievement of those revolutionary projects in education. Thus, ICT teachers' attitudes, competencies, and willingness to embrace technology will have an impact on meeting the goals of the projects focusing on the successful integration of technology into the educational processes.

\section{Purpose of the Study}

This study examined the professional growth of ICT teachers in terms of changes in their perceptions of teaching and their pedagogical and subject-matter knowledge during their professional careers. It also aimed to shed some light on ICT teachers' awareness of the importance of integrating technology into teaching and learning activities and to touch upon the effective use of technology in the classroom. The study posed the following specific research questions: 
1. What is the professional growth of elementary education ICT teachers in terms of their perceptions about teaching?

2. What is the professional growth of elementary education ICT teachers in terms of their own pedagogic and subject matter competencies?

3. To what extent do elementary education ICT teachers use their pedagogical and subjectmatter skills in their teaching practices?

The paper continues with the detailed explanation of what ICT teaching is, the role of the teacher and their professional growth.

\section{ICT Teaching}

Despite the growing use of technology in the classroom, there is a lack of studies in the literature that investigates the role of ICT teachers and their use of technology in the classroom. The title and/or role of those teachers whose main responsibility is the integration of technology varies from country to country and includes 'ICT coordinators', 'technology coordinators', and 'media specialists' (Law \& Plomp, 2003). Moreover, terms such as 'computer literacy', 'ICT literacy', and 'IT literacy' are used interchangeably.

The integration of computers into the curriculum usually occurs in one of two ways: either a separate course is dedicated to computer usage, or the computer is used as a 'helping tool' on projects (EURYDICE, 2001). In the 1990s, computers tended to be taught as a separate school subject at the secondary level in many European countries, usually in a course titled something along the lines of 'Computer Literacy in Education' (Kington \& Harris 2003; Law \& Plomp 2003; Reignier, 2003). Recently, however, the focal point in technology integration has shifted away from learning about ICT to learning through ICT. In many cases, the main concern involves teaching students how to use the Internet or educational software in their assignments both inside and outside the classroom. In developed countries such as western European countries and the United States, ICT competencies are generally taught in the classroom as part of other subjects (Anderson \& Dexter, 2003; Zander, 2003), with teachers of non-computer subjects embedding ICT in their teaching activities. However, in a few countries, such as England, ICT skills continue to be taught as a separate course, although students also acquire ICT skills by using new technologies in their learning activities (Law \& Plomp, 2003). Kington and Harris (2003) have found that teachers in England insert ICT into other subject areas such as mathematics, science, and English. According to Law and Plomp (2003), offering ICT as a separate course requires teachers who may also teach related courses such as programming, networking, and software development to have expertise in computing. This type of implementation occurs in countries such as Greece and Bulgaria (EURYDICE, 2001), especially in vocational schools. In Turkey, students in K8 schools are offered a one-hour optional computer course where they learn basic computer applications such as desktop publishing, spreadsheets, and presentations. Regardless of method, if ICT is used in the basic education curriculum, it is unavoidable that all teachers will be affected to some degree or another and will thus require some basic ICT skills.

In 1998, Turkey's Higher Education Council redesigned the curricula of Turkish education faculties to include new departments of Computer Education and Instructional Technology (CEIT) in order to prepare the groundwork for the implementation of rapidly developing technologies in the schools. Moreover, in order to improve the quality of basic education, the Ministry of National Education (MoNE), in line with international practices, established 'IT rooms' (IT classes with audio-visual equipment) in basic education schools across the country (Yildirim, 2007). Students graduating from CEIT departments serve as ICT teachers in elementary education schools and are generally responsible for the effective use of these IT rooms. Pre-service ICT teachers who complete a university education are expected to be competent in the domains of both subject matter (use and integration of technology in education) and pedagogy as a prerequisite for fulfilling one 
of their most important roles as teachers, i.e., integrating technology into their lessons. ICT teachers' competencies, thoughts about teaching, interaction with students and other teachers, and the obstacles faced in terms of technology integration are critical factors for the effective integration of technology in the schools.

In addition, according to studies about technology integration the factors such as technical knowledge of teachers regarding the technology to be used, their expectations about the benefits of this technology for educational processes, their interest for and attitude toward technology, and their knowledge and concerns about technology use affect teachers' adoption of the process (Ertmer, 2005; Hew \& Brush, 2007; Jimoyiannis, 2010; Kopcha, 2012; Marwan \& Sweeney, 2010; Mishra \& Koehler, 2009; Windschitl \& Sahl, 2002; Yildirim, 2007). Therefore, to overcome those obstacles teachers are required to keep themselves up to date in their field. Danner and Pesu (2013) agree that it is necessary to train teachers with ICT skills for effective teacher development that will foster a responsibility in them to help their students gain critical thinking skills.

\section{Professional Growth of Teachers}

Professional growth is defined as changes in the performance, knowledge, views, or perceptions of teachers (Clarke \& Hollingsworth, 2002; Grossman, 1992; Kagan, 1992; Ross \& Bruce, 2007). Significant changes in beliefs and attitudes result in positive changes in the classroom practices, thus changing teacher practices leads to changes in student learning outcomes (Kagan, 1992).

University teacher-training programs need to connect theoretical courses with everyday life so that what teacher candidates are taught is in harmony with actual teaching practices. Koca and Sen (2006) point out that teachers adapt the training they receive in schools in accordance with their own views and thoughts on education. Teachers' thoughts about teaching are important factors within the school environment that has bearing on a school's ability to fulfill its mission and vision since a student's achievement and attitude towards a school are dependent upon teacher practices and professional growth (Brookhart \& Freeman, 1992; Mahlios \& Maxson, 1995).

In addition, pre-service teachers who satisfactorily complete their university coursework and teaching practicums are assumed to be ready to enter the field of teaching. However, in their initial years of teaching, some teachers suffer burnout, disillusionment, and dissatisfaction, while others perform satisfactorily, consider themselves effective, and remain content with their choice of career (Block, 2008). The different responses may be explained by differences in personal attributes of teachers, job-related factors, and teacher-education programs (Block, 2008; McDiarmid, 1990). Block (2008) emphasizes that, although teaching is a complex and demanding profession, the quick transition from training to practice leads to problems for beginning teachers.

\section{Methodology}

This study relied on a combination of quantitative and qualitative traditions, since neither method was considered sufficient in itself for answering the broad questions investigated in this study.

\section{Instruments}

Data was collected on elementary education ICT teachers' perceptions about teaching and about their pedagogical and subject-matter competencies. The first phase of the study collected quantitative data using a questionnaire survey developed by the researchers from existing instruments

after a literature review. In the second phase of the study the researchers collected qualitative data through the interviews and observations they conducted. 
In the first phase of the study, participants were asked to respond to 61 statements using a Likert Scale of 1-5, with 1 representing 'fully disagree' or 'incompetent' and 5 representing 'fully agree' or 'fully competent'. Items were divided into three sections, as follows:

1. Teachers' Perceptions of Teaching (TPoT) (16 items): general perceptions about the role of ICT teachers and professional satisfaction;

2. Pedagogical Competencies (22 items): student recognition/assessment and the teaching process;

3. Subject-Matter Competencies (23 items): technological concepts and implementation, designing a learning environment, professional development.

The researchers developed items in the TPoT section by taking expert opinions into account. The researchers adapted items in the sections on pedagogical and subject-matter competencies from MoNE competency indicators encompassing skills such as following innovation, self-

development and transferring knowledge to the teaching-learning environment (MoNE, 2005). The Cronbach-Alpha reliability value of the overall survey was calculated as 0.92 . Descriptive statistics, such as frequencies, means, and standard deviations were calculated by using the statistical analysis software SPSS15.0.

In the second phase of the study, qualitative data was gathered through interviews and observations. Structured interviews were conducted according to an interview protocol containing 12 close-ended, standardized questions related to perceptions of teaching and pedagogical and subject-matter competencies. Direct observations were conducted in order to determine how ICT teachers integrated and transferred their pedagogical and technological (subject-matter) knowledge into their teaching practice. Strauss and Corbin's (1998) analytical strategies (open coding, axial coding, and selective coding) were used to examine the qualitative findings. After using these strategies, themes and codes were extracted from participants' responses by taking into account the research questions under consideration. Experts and peers reviewed the resulting coding system and codes. Reliability and validity were taken into consideration in all phases of the research. Analyses were also conducted that compared quantitative and qualitative data. All procedures (scales, interviews and observations) were conducted with the consent of the participants.

\section{Participants}

The study population comprised all in-service ICT teachers who graduated from CEIT departments. Permission to conduct the survey was given by the MoNE, and the participating teachers were all volunteers. Surveys were sent via e-mail to several popular e-mail groups established among ICT teachers with the help of the MoNE. In total, responses were obtained from 104 inservice teachers (49 male, 55 female). Participants in the qualitative phase of the study were selected based on convenience sampling and included in-service teachers in K-8 state and private schools in the Turkish capital, Ankara.

The sample encompassed a wide socio-economic range and included graduates of different universities and was thus considered representative of the population of all in-service ICT teachers in Turkey. Moreover, qualitative data was collected from teachers selected from among the total participants based on quantitative information (sex, gender, urban/rural school location, number of IT class per school, number of students per class, teacher perceptions) obtained in phase 1 of this study and on teacher availability. In total, qualitative data was collected through interviews with 12 in-service teachers ( 6 male, 6 female) with experience ranging from 1-4 years and through classroom observations of 4 teachers ( 2 male, 2 female). The interviews included 12 main questions that addressed teacher perceptions and pedagogic and subject-matter knowledge, such as 'What do you think about ICT teaching as a profession?'; 'How do you design your lesson involving appropriate technological tools?'; and 'How do you evaluate your students at the end of 
the lesson?'. Observations considered the context of the IT classroom and the pre-instructional (planning), instructional and post-instructional (assessment) processes.

\section{Findings}

\section{Quantitative Results}

Table 1 shows that the majority of participating in-service teachers had been teaching 1-4 years. Only 7.7 percent $(n=8)$ had more than 4 years of teaching experience, and only 27 percent $(n=28)$ were engaged in post-graduate studies.

Table 1: Demographics of the participants $(n=104)$

\begin{tabular}{|c|c|c|}
\hline Characteristic & $\mathbf{N}$ & $\%$ \\
\hline \multicolumn{3}{|c|}{ Years of experience } \\
\hline 1 & 26 & 25 \\
\hline 2 & 30 & 28.85 \\
\hline 3 & 24 & 23.1 \\
\hline 4 & 12 & 11.54 \\
\hline More than 4 & 8 & 7.7 \\
\hline \multicolumn{3}{|l|}{$\underline{\text { Sex }}$} \\
\hline Male & 49 & 47.0 \\
\hline Female & 55 & 53.0 \\
\hline \multicolumn{3}{|c|}{ Post-Graduate Degree } \\
\hline Master & 24 & 23 \\
\hline $\mathrm{PhD}$ & 4 & 4 \\
\hline None & 65 & 62.5 \\
\hline
\end{tabular}

Regarding participants' responses to the questionnaire (see Table 2), mean scores $(M)$ of the responses to statements related to perceptions of teaching ranged from a high of 4.26 for the item 'I see ICT teachers as contributing to the development of the technological knowledge of society' to a low of 2.29 for the item 'ICT teaching is not a challenging profession compared to other areas of teaching'. Mean scores of the responses to items related to pedagogical competency ranged from a high of 4.68 for the item 'Listening to students and showing sensitivity in providing answers to their questions' to a low of 3.52 for 'Checking the reliability and validity of instruments'. Mean scores of the responses to items related to subject-matter competency ranged from a high of 4.69 for 'Introducing and making practical use of peripheral hardware (printers, scanners, digital cameras, etc.).' to a low of 2.97 for 'Designing lessons involving appropriate technological tools that will cater to learners with special needs (mentally and physically handicapped)'. All responses of the participants to questionnaire items can be seen in the appendix.

Overall, in-service teachers had positive perceptions of teaching $(M=3.56)$, although the perceptions of male teachers $(M=3.71)$ were higher than those of female teachers $(\mathrm{M}=3.44)$. Male teachers also had higher mean scores in terms of perceived subject-matter competency $(M=4.22)$ than female teachers $(M=4.00)$, whereas mean scores for perceived pedagogical competency were similar for female and male in-service teachers (Female: $M=4.15$; Male: $M=4.13$ ). 
Table 2: Participants' Responses to some Items of the Questionnaire (n=104)

\begin{tabular}{l|l|l}
\hline PERCEPTIONS OF TEACHING & $M$ & $S D$ \\
\hline $\begin{array}{l}\text { 4) I see ICT teachers as contributing to the development of the technological knowledge of } \\
\text { society. }\end{array}$ & 4.26 & 0.98 \\
5) In my opinion, other teachers (e.g. math, science, etc.) view ICT teachers as role-models \\
when incorporating the use of technology into their classrooms. & 2,98 & 1,12 \\
7) ICT teaching is not a challenging profession compared to other areas of teaching. & 2.29 & 0.95 \\
$\begin{array}{l}\text { 16) I think ICT teachers help their students to become more successful learners by directing } \\
\text { them towards research. }\end{array}$ & 4.09 & 0.84 \\
\hline PEDAGOGICAL KNOWLEDGE & & \\
\hline $\begin{array}{l}\text { 17) Making effective use of verbal and body language (posture, expression, hand/arm } \\
\text { movement, etc.) at a level appropriate for students. }\end{array}$ & 4.40 & 0.65 \\
19) Checking the reliability and validity of the instrument. & 3.52 & 1.00 \\
20) Analyzing data using ICT in student assessments. & 3.79 & 1.09 \\
22) Listening to students and showing sensitivity in providing answers to their questions. & 4.68 & 0.52 \\
\hline SUBJECT MATTER KNOWLEDGE & & \\
\hline $\begin{array}{l}\text { 1) Installing the required software programs, regularly maintaining the system and updat- } \\
\text { ing/removing software as necessary. }\end{array}$ & 4.64 & 0.70 \\
5) Introducing and making practical use of peripheral hardware (printers, scanners, cameras, \\
etc.). \\
$\begin{array}{l}\text { 19) Designing and developing appropriate educational software in line with course content, } \\
\text { learners' multiple intelligences and learning styles. } \\
\text { 21) Designing lessons involving appropriate technological tools that will cater to learners } \\
\text { with special needs (mentally and physically handicapped). }\end{array}$ & 3.65 & 0.99 \\
\hline
\end{tabular}

\section{Qualitative Results}

Interviews and observations conducted with some of the participants showed that teachers believed that instructional technology was very important for teaching and learning activities. Their responses also indicated that they considered ICT teaching as a profession to be different from other areas of teaching. Table 3 summarizes the general themes that were extracted from inservice teachers' responses to interview questions.

\section{Table 3: Themes emerging through participant interviews}

\begin{tabular}{ll}
\hline Variable & Theme \\
\hline Perceptions & Students' attitudes towards an ICT course and teachers \\
& Students' treat the ICT course as a time for playing games \\
& Students' learning levels and level of ICT knowledge \\
& Role of the ICT teacher \\
Pedagogical & Teacher-student communication \\
Competency & Limitations on classroom time affect pedagogical requirements \\
& Need for real-life projects \\
& Classroom management/ICT class environment \\
\hline
\end{tabular}




\begin{tabular}{ll}
\hline Variable & Theme \\
\hline Subject-Matter & Need for in-service training \\
Competency & Working cooperatively and preparing teaching materials with other teachers \\
& $\begin{array}{l}\text { Number of IT class and scarcity of computers } \\
\text { Treated as 'technical support' in the school. }\end{array}$ \\
\hline
\end{tabular}

\section{Perceptions of Teaching}

Most of the ICT teachers interviewed $(n=8)$ noted that student interest in the course and the teacher affected their perceptions of teaching. Since there are many discouraging factors as well as interesting ones for students in IT classes such as games, chat, surfing on the internet and so on, it becomes a challenge for ICT teachers to provide effective classroom management and to get students' attention on the lesson.

For example, according to one female teacher who had been teaching for 3 years:

The students come to the IT class to play games and to chat. Almost all of the students have an e-mail account. Some of them can use instant messaging program, and they explain how to use the program to students who don't know how to use it.

Another teacher stated:

When students come to the IT class, they are thinking about playing games. They immediately start to play a game on the computer. When I don't allow them to play, they hate me, and then I become a bad teacher.

These statements are in line with classroom observations. For example, in one class, the teacher permitted students to play a game in the IT class; the students liked this, and they immediately started to play games on the computers.

Most teachers $(n=10)$ felt that students should be provided more opportunities to use the computers. They stressed that computers should be utilized in all courses to as great an extent as possible and that IT classes should be made available to students outside of school hours. Teachers emphasized the importance of providing students with continuous access to technology and stressed that efficient use of the IT classes was more important than equipping them with the latest technologies. As one teacher pointed out:

The use of the computers should not be limited to computer courses. For example, students could be provided with an environment in which they could use the technology outside school hours.

Most of the teachers interviewed $(n=8)$ also thought that the role of the ICT teachers should be changed or re-described, bearing in mind the frequent complaint that they are regarded as technical service staff and are made responsible for maintaining school technology. One teacher illustrates this perception in the following statement:

I accept responsibility for the computers in the IT class, and I can repair them if necessary; however, I cannot cope with all the computers on my own. I should have assistants to help me. Sometimes I ask a student to help me, but I am not sure how right that is.

Another teacher explained:

Sometimes I am afraid of my job. Since we are ICT teachers, everybody expects us to know everything about computers. However, as you know, we can't know everything. 
It was also suggested $(n=8)$ that ICT teaching be associated with other subject areas; in other words, having ICT teachers work together with other teachers would result in more effective integration of technology in the schools. As one ICT teacher explained:

I sometimes train other teachers, especially on software programs. I think this is important because we cannot be solely responsible for using technology in the schools; other teachers must begin to use it as soon as possible.

\section{Pedagogical Competency}

Participants felt that their university training did not correspond to their real-life teaching situations and that as a result, as several participants mentioned, teachers were required to develop their own teaching strategies appropriate for the actual context. For example, one teacher commented:

I never once benefited from my courses in ICT teaching and pedagogy. From the day I started teaching, I began developing my own teaching strategies in line with my own classroom experience and that of other teachers and with the students' learning levels in mind.

According to participants, teachers are encouraged to implement projects in the IT class that make the lesson more enjoyable for students. For instance, one male teacher who had been teaching for years commented:

I have been applying the project-based teaching model. When I teach Word, Excel, and Google to sixth-grade students, I relate these subjects to the project of developing a magazine. The children enjoy the lessons very much, and they learn very quickly and efficiently.

Almost all participants $(n=10)$ highlighted how computers changed the atmosphere of the classroom, stating that despite their familiarity with the computer environment, they sometimes had trouble with classroom management and student interaction in the IT class. For example, one teacher recalled:

All the students were talking. They asked for permission to explain the game to their friends. They were giving each other hints, but I couldn't do anything about it. I couldn't decide what to do...I was looking forward to break time.

Problems and challenges which teachers encounter and their views mentioned above were highlighted during the teacher observations conducted within the framework of this study. In one class, for example, student-teacher interaction remained limited due to the high number of students in the classroom, and the teacher was forced to issue warnings to students who were being disruptive.

\section{Subject-Matter Competency}

All teachers strongly agreed on the need to update the ICT teaching curriculum on an annual basis due to rapid developments in technology. One teacher stated, "I feel myself fully competent to teach something about technology to students. However, this doesn't matter, since technology is changing rapidly all the time." Class observations showed that in fact, teachers did not follow the current curriculum.

Moreover, teachers $(\mathrm{n}=8)$ argued that they should not only teach students how to use computers and some computer programs, but that they should help other teachers to make use of technology in all courses on an ongoing basis. According to their views, ICT teachers could cooperate with other classroom teachers in developing material that would allow those teachers to carry out their 
lessons in a more enjoyable way and make it easier for students to learn their other subjects. One ICT teacher who had been teaching for two years reported:

I helped the math teacher to develop materials for his lesson. We examined a program he downloaded from the Internet. He was very glad to have my help.

During the class observations, teachers were clearly seen to be well-prepared, to use a variety of technological materials and teaching strategies, and to help other teachers to incorporate technology in their teaching activities.

Half of the participating teachers $(n=6)$ also indicated an interest in attending in-service training programs to help them keep up to date. Teachers also stated that having contact with universities, school administrators and the MoNE would help them to perform their roles more effectively. One teacher who had been teaching for three years explained his ideas as follows:

The ICT teachers are not provided with in-service training programs. However, we are the first ones who need to adapt to the technology. I am trying to do my best, but sometimes I cannot cope with it. I think we should always maintain co-operation with universities.

\section{Discussion}

Table 4 summarizes the results of this study.

Table 4: Summaries of the findings

\begin{tabular}{|c|c|c|}
\hline Result of the study & Related studies & Contribution to the literature \\
\hline $\begin{array}{l}\text { Although teachers have positive per- } \\
\text { ceptions about ICT teaching and about } \\
\text { their subject-matter and pedagogical } \\
\text { knowledge, some negative points re- } \\
\text { lated to students interest in technology } \\
\text { and attitudes in the IT classes affect } \\
\text { teachers' interest about profession. }\end{array}$ & $\begin{array}{l}\text { Current literature (Angeli \& } \\
\text { Valanides, 2009; Jang \& } \\
\text { Tsai, 2012; König et al., } \\
\text { 2011; Mishra \& Koehler, } \\
\text { 2006) states that there is a } \\
\text { connection between teacher } \\
\text { competencies, teacher per- } \\
\text { formance and in-class } \\
\text { teaching practice }\end{array}$ & $\begin{array}{l}\text { Teachers' perceptions and com- } \\
\text { petencies are the important fac- } \\
\text { tors for their professional growth. }\end{array}$ \\
\hline $\begin{array}{l}\text { According to ICT teachers, their uni- } \\
\text { versity education alone is not enough to } \\
\text { be successful in their teaching careers. }\end{array}$ & $\begin{array}{l}\text { Literature (Birgök \& } \\
\text { Vuranok, 2010) confirms } \\
\text { that teachers cannot access } \\
\text { systematically the cutting- } \\
\text { edge information after } \\
\text { graduation from university. }\end{array}$ & $\begin{array}{l}\text { Annual in-service training pro- } \\
\text { grams especially about rapidly } \\
\text { developing educational technolo- } \\
\text { gies should be provided to teach- } \\
\text { ers in order to ensure their pro- } \\
\text { fessional development. }\end{array}$ \\
\hline $\begin{array}{l}\text { Extracurricular responsibilities of the } \\
\text { ICT teachers, decrease their educational } \\
\text { efficiencies }\end{array}$ & $\begin{array}{l}\text { Goktaş and Topu (2012) } \\
\text { confirm this by stating that } \\
\text { students and teachers in } \\
\text { schools have many expecta- } \\
\text { tions from ICT teachers. }\end{array}$ & $\begin{array}{l}\text { ICT teachers' workload and ex- } \\
\text { pectations of students and other } \\
\text { teachers affect ICT teachers' } \\
\text { performance negatively. }\end{array}$ \\
\hline $\begin{array}{l}\text { Professional and environmental charac- } \\
\text { teristics influence ICT teachers' per- } \\
\text { formance }\end{array}$ & $\begin{array}{l}\text { Individual and contextual } \\
\text { factors affect the profes- } \\
\text { sional satisfaction of the } \\
\text { teachers (Deryakulu \& } \\
\text { Olkun, 2007; Kagan, 1992) }\end{array}$ & $\begin{array}{l}\text { Teacher salaries and employment } \\
\text { opportunities are important fac- } \\
\text { tors in the job-satisfaction of ICT } \\
\text { teachers }\end{array}$ \\
\hline
\end{tabular}


The present study examines the professional growth of elementary education ICT teachers in terms of their perceptions about ICT teaching and about their pedagogical and subject-matter competencies. According to studies (Clarke \& Hollingsworth, 2002; Kagan, 1992; Ross \& Bruce, 2007) changing in the behavior, knowledge, and perceptions of the teachers are the indicators of the professional growth.

In general, the findings show teachers have positive perceptions about ICT teaching and about their subject matter and pedagogical knowledge. At the same time, the findings point to certain negative perceptions related to students' interest in technology and attitudes in the IT class, as well as about IT classes, that affect teacher interest in the profession. Researchers pointed out that teaching is a highly complex activity that requires extensive knowledge (Arends, 2001; Jang \& Tsai, 2012; Mishra \& Koehler, 2006). Moreover, studies (Angeli \& Valanides, 2009; König et al., 2011) stress that there is a connection between teacher competencies, teacher performance and inclass teaching practice.

According to the results, ICT teachers think that their university training is insufficient to meet their practices in their profession. This might be the reason that they develop their own teaching strategies according to their teaching contexts. Helping students create a bridge between what they know and real life practice is a major challenge in higher education disciplines, especially in the applied disciplines like education, in which professional knowledge is updated continuously by the practices in real life. A recent study conducted by Birgök and Vuranok (2010) shows that teachers forget some part of their knowledge, which they gained during their university education, and cannot access systematically the newly produced information after graduation from university. Teachers cannot sufficiently participate in the life-long learning activities because of the reasons such as time limitation and intensive work schedule.

Teachers' responses implied that their in-class performance is affected by several specific factors: lack of time to successfully complete pedagogical requirements; difficulties in communicating effectively with students in the IT class; problems related to classroom design; and challenges related to classroom management. Rather than just teaching basic computer applications, ICT teachers prepare teaching materials using developing technologies such as internet-supported environment and the use of educational software etc. Moreover, ICT teachers help other teachers to use ICT technology in the classroom. In addition to those roles, they have also extracurricular roles. Assisting teachers and administrators and dealing with the hardware and software problems of technological tools in schools are at the top of ICT teachers' extracurricular roles. It can be concluded that the in-class and extracurricular responsibilities of ICT teachers may decrease educational efficiency. The study conducted by Göktaş and Topu (2012) supports the obtained results of this study by reporting that students and teachers in schools have many expectations from ICT teachers such as working as an expert or technical staff.

Based on results of the study, factors affecting teachers' performance in the profession can be categorized as either relating to professional or environmental characteristics. Professional characteristics include teaching roles, teacher salaries, and difficulties in maintaining up-to-date technology and employment opportunities in the private sector. Environmental characteristics include poor organization and poorly equipped IT class, including a lack of sufficient computers in the class and outdated curricula. In addition, another environmental factor is lack of interest on the part of students. For example, inability of students to use technological tools because of insufficient knowledge or insufficient technical support causes students to have negative attitudes toward technology (Manochehri \& Sharif, 2010).

These results are in line with previous studies. For example, a study by Deryakulu and Olkun (2007) analyzed ICT teachers' online discussion messages with regard to job satisfaction and found the most frequently mentioned problems to be uncertainty about the role of the ICT 
teacher, lack of technological infrastructure, an outdated curriculum and inadequate educational policies. Similarly, a study by Kagan (1992) that investigated the individual and contextual factors influencing the professional satisfaction of teachers who have graduated or are about to graduate from a teacher-education program found teacher satisfaction to be affected by the amount of information they possessed about their students and by their previous opinions and perceptions regarding teaching and their ability to readjust these opinions and perceptions to their new environment. In a study examining the influence of workplace conditions on teacher satisfaction, Ma and MacMillan (1999) found that workplace conditions, administrative control and teacher competencies all affected teacher satisfaction. Several studies have emphasized the relationship between teacher job satisfaction and achievement. For example, Block (2008) found teacher satisfaction to be an important factor in teachers' evaluations of their roles and performance in an educational setting.

\section{Conclusion}

In conclusion, the growing needs to integrate ICT in schools and the various options in this regard have engendered new roles for all stakeholders in the area of education. Law and Plomp (2003) claim that teachers are unable to fulfill these new roles and tasks by themselves. The findings of the present study suggest that the effective use of technology in elementary education is largely dependent upon the active involvement of the ICT teacher in the process of technology integration. In order to ensure such active involvement, stakeholders such as the MoNE, universities, and teacher-educators should develop and employ new policies and projects that involve ICT teachers in the decision-making and planning processes. Moreover, given students' interests in computer games, as found in this study, research may be conducted that looks at ways of using educational computer games in the classroom (Hainey et al., 2011; McDonald \& Hannafin, 2003; Mitchell \& Fox, 2001). Finally, considering the rapid development of technology and its indispensability in education, ICT teachers should be provided with regular in-service training to allow them to keep up with cutting-edge technology. This could be achieved by offering updated professional development programs to teachers on an annual basis.

\section{References}

Anderson, R. E., \& Dexter, S. (2003). National policies and practices on ICT in education: United States. In T. Plomp, R. Anderson, N. Law, \& A. Quale (Eds.), Cross-national information and communication technology policies and practices in education ( $p$ p 569-580). Greenwich, Connecticut: IAP.

Angeli, C., \& Valanides, N. (2009). Epistemological and methodological issues for the conceptualization, development, and assessment of ICT-TPCK: Advances in technological pedagogical content knowledge (TPCK). Computers \& Education, 52,154-168.

Arends, R. I. (2001). Learning to teach (5th ed.). NewYork: McGraw-Hill Companies.

Birkök, M., C., \& Vuranok, T. G. (2010). Fulfilling the need for knowledge via distance education: A university program proposal. International Journal of Human Sciences 7(2), 418-444.

Block, A. A. (2008). Why should I be a teacher? Journal of Teacher Education, 59(5), 416-427.

Brookhart, G., \& Freeman, D. (1992). Characteristics of entering teaching candidates. Review of Educational Research, 62, 37-60.

Clarke, D., \& Hollingsworth, H. (2002). Elaborating a model of teacher professional growth. Teaching and Teacher Education, 18(8), 947-967.

Clements, D., \& Sarama, J. (2003). Young children and technology: What does the research say? Young Children, 58(6), 34-40. 
Danner, R. B., \& Pessu, C. O. A. (2013). A survey of ICT competencies among students in teacher preparation programmes at the University of Benin, Benin City, Nigeria. Journal of Information Technology Education: Research 12, 33-49. Retrieved from http://www.jite.org/documents/Vol12/JITEv12ResearchP033-049Danner1160.pdf

Deryakulu, D., \& Olkun, S. (2007). Analysis of computer teachers' online discussion forum messages about their occupational problems. Educational Technology \& Society, 10(4), 131-142.

Donnelly, D., McGarr, O., \& O’Reilly, J. (2011). A framework for teachers' integration of ICT into their classroom practice. Computers \& Education, 57(2), 1469-1483.

EURYDICE. (2001). Basic indicators on the incorporating of ICT into European education systems- Facts and figures. European Commission. Brussels.

Ertmer, P. A. (2005). Teacher pedagogical beliefs: The final frontier in our quest for technology integration? Educational Technology Research and Development, 53(4), 25-39.

Göktaş Y., \& Topu, F. B. (2012). ICT teachers' assigned roles and expectations from them. Educational Sciences: Theory \& Practice, 12(1), 473-478.

Grossman, P. L. (1992). Why models matter: An alternate view on professional growth in teaching. Review of Educational Research, 62(2), 171-179.

Hainey, T., Connolly, T., Stansfield, M., \& Boyle, E. (2011). The differences in motivations of online game players and offline game players: A combined analysis of three studies at higher education level. Computers \& Education 57(4), 2197-2211.

Hew, K. F., \& Brush, T. (2007). Integrating technology into K-12 teaching and learning: Current knowledge gaps and recommendations for future research. Education Technology Research \& Development, $55,223-252$

Jang, S.-J., \& Tsai, M.-F. (2012). Exploring the TPACK of Taiwanese elementary mathematics and science teachers with respect to use of interactive whiteboards. Computers \& Education, 59, 327-338.

Jimoyiannis, A. (2010). Designing and implementing an integrated technological pedagogical science knowledge framework for science teachers' professional development. Computers \& Education, 55, $1259-1269$.

Kagan, D. M. (1992). Professional growth among preservice and beginning teachers. Review of Educational Research, 62(2) 129-169.

Kington, A., \& Harris, S. (2003). National policies and practices on ICT in education: England. In T. Plomp, R. Anderson, N. Law, \& A. Quale (Eds.), Cross-national information and communication technology policies and practices in education (pp 197-211). Greenwich, Connecticut: IAP.

Koca, S. A., \& Sen, A. I. (2006). The beliefs and perceptions of pre-service teachers enrolled in a subjectarea dominant teacher education program about effective Education. Teaching and Teacher Education, 22, 946-960.

Kopcha, T. J. (2012). Teachers' perceptions of the barriers to technology integration and practices with technology under situated professional development. Computers \& Education, 59(4), 1109-1121.

König, J., Blömeke, S., Paine, L., Schmidt, W. H., \& Hsieh, F. (2011). General pedagogical knowledge of future middle school teachers: On the complex ecology of teacher education in the United States, Germany, and Taiwan. Journal of Teacher Education, 62, 188-201.

Kulik, J. (2002). School mathematics and science programs benefit from instructional technology. Washington, DC: National Science Foundation, Retrieved 10 August 2012 from http://www.nsf.gov/sbe/srs/infbrief/nsf03301/start.htm

Law, N., \& Plomp, T. (2003). Curriculum and staff development for ICT in Education. In T. Plomp, R. Anderson, N. Law, \& A. Quale (Eds.), Cross-national information and communication technology policies and practices in education (pp 15-31). Greenwich, Connecticut: IAP. 
Ma, X., \& MacMillan, R. B., (1999). Influences of workplace conditions on teachers' job satisfaction. The Journal of Educational Research, 93(1), 39-47.

Mahlios, M., \& Maxson, M. (1995). Capturing preservice teachers' beliefs about schooling, life and childhood. Journal of Teacher Education, 46, 192-199.

Manochehri, N. N. \& Sharif, K. (2010). A model-based investigation of learner attitude towards recently introduced classroom technology. Journal of Information Technology Education, 9, 31-52. Retrieved from http://www.jite.org/documents/Vol9/JITEv9p031-052Manochehri744.pdf

Marwan, A., \& Sweeney, T. (2010). Teachers' perceptions of educational technology integration in an Indonesian polytechnic. Asia Pacific Journal of Education, 30(4), 463-476.

McDiarmid, G. W. (1990). Challenging prospective teachers' beliefs during early field experience: A quixotic undertaking. Journal of Teacher Education, 41, 12-20.

McDonald, K. K., \& Hannafin, R. D. (2003). Using web-based computer games to meet the demands of today's high-stakes testing: A mixed method inquiry. Journal of Research on Technology in Education, 35, 459-472.

Minor, L. C., Onwuegbuzie, A. J., Witcher, A. E., \& James, T. I. (2002). Preservice teachers' educational beliefs and their perceptions of characteristics of effective teachers. The Journal of Educational Research, 96(2), 116-127.

Mishra P., \& Koehler, M. J. (2006). Technological pedagogical content knowledge: A framework for teacher knowledge. Teachers College Record, 108(6), 1017-1054.

Mishra, P., \& Koehler, M. J. (2009). Teachers' technological pedagogical content knowledge and learning activity types: Curriculum-based technology integration reframed. Journal of Research on Technology in Education, 41(4), 393-416.

Mitchell, M. J., \& Fox, B. J. (2001). The effects of computer software for developing phonological awareness in low-progress readers. Reading Research and Instruction, 40, 315-332.

MoNE. (2005). Information technology teachers' subject matter competencies. Ministry of National Education: Ankara. Retrieved 22 May 2012 from http://otmg.meb.gov.tr/alanbt.html

MoNE. (2012). Ministry of National Education, completed projects. Retrieved 25 September 2012 from http://projeler.meb.gov.tr/pkmtr/

Reigner, C. (2003). National policies and practices on ICT in education: France. In T. Plomp, R. Anderson, N. Law, \& A. Quale (Eds.), Cross-national information and communication technology policies and practices in education (pp 233-247). Greenwich, Connecticut: IAP.

Rohaan, J. E., Taconis, R., Wim, M. G., \& Jochems, W. M. G. (2010). Reviewing the relations between teachers' knowledge and pupils' attitude in the field of primary technology education. International Journal of Technology and Design Education, 20, 15-26.

Ross, J. A, \& Bruce, D. C. (2007). Teacher self-assessment: A mechanism for facilitating professional growth. Teaching and Teacher Education, 23, 146-159.

Strauss, A., \& Corbin, J. (1998). Basics of qualitative research: Techniques and procedures for developing grounded theory. Thousand Oaks, CA: Sage Publications.

Yildirim, S. (2007). Current utilization of ICT in Turkish basic education schools: A review of teacher's ICT use and barriers to integration. International Journal of Instructional Media, 34(2), 171-186.

Windschitl, M., \& Sahl, K., (2002). Tracing teachers' use of technology in a laptop computer school: The interplay of teacher beliefs, social dynamics, and institutional culture. American Educational Research Journal, 39(1), 165-205.

Zander, R. S., (2003). National policies and practices on ICT in education: Germany. In In T. Plomp, R. Anderson, N. Law, \& A. Quale (Eds.), Cross-national information and communication technology policies and practices in education (pp 569-580). Greenwich, Connecticut: IAP. 


\section{Appendix: \\ Participants' Responses to Questionnaire Items ( $n=104)$}

\begin{abstract}
PERCEPTIONS OF TEACHING
1) I think I have special skills about the field of ICT teaching

2) I find the teaching in the IT class to be tiresome.

3) As a profession, ICT teaching is not attractive to me

4) I see ICT teachers as contributing to the development of the technological knowledge of society.

5) In my opinion, other teachers (e.g. math, science, etc.) view ICT teachers as role models when incorporating the use of technology into their classrooms.
\end{abstract}

6) I believe that ICT teachers receive more respect from society than other teachers (e.g. math, science, etc.).

7) ICT teaching is not a challenging profession compared to other areas of teaching.

8) If I took the university entrance exams again I would still choose to study ICT education

9) I find being an ICT teacher enjoyable

10) Being ICT teacher is an exciting job.

11) For me, ICT teaching is not an attractive profession

12) I believe that ICT teachers make a difference in the social lives of students

13) In my opinion, students like ICT teachers better than other teachers at the school.

14) I think ICT teachers help their students to cultivate themselves

15) I see ICT teaching to be a more sought-after and distinguished profession when compared to other branches of teaching.

16) I think ICT teachers help their students to become more successful learners by directing them towards research.

\section{PEDAGOGICAL KNOWLEDGE}

1) Clearly explaining the purpose, aims and behavior in lesson plans.

2) Organizing learning-teaching activities that provide students with direction in order to achieve the aims and behaviors of the lesson plan.

3)Taking into consideration individual differences among students and learning styles in planning the lesson.

4) Including in the lesson plan a strategy for how ICT will be used.

5) Considering student characteristics and facilitating learning when organizing classroom setting.

6) Ensuring that students are able to recommend and participate in a variety of activities.

7) Ensuring cohesion by relating the subject of the lesson plan to that of previous and subsequent lessons.

8) Benefiting from the use of methods and techniques that are appropriate for students' ages, previous level of education and skills.

9) Using time in a planned, productive manner.

10) Creating opportunities to relate what students learn to real life.

\begin{tabular}{|c|c|}
\hline$M$ & $S D$ \\
\hline 3.51 & 1.13 \\
\hline 3.66 & 1.11 \\
\hline 3.55 & 1.31 \\
\hline 4.26 & 0.98 \\
\hline 2,98 & 1,12 \\
\hline 3.68 & 1.22 \\
\hline 2.29 & 0.95 \\
\hline 3.30 & 1.12 \\
\hline 3.97 & 1.14 \\
\hline 3.61 & 1.21 \\
\hline 3.52 & 1.32 \\
\hline 3.75 & 0.99 \\
\hline 3.87 & 1.00 \\
\hline 3.86 & 1.00 \\
\hline 3.46 & 1.22 \\
\hline 4.09 & 0.84 \\
\hline & \\
\hline 4.08 & 0.83 \\
\hline 4.08 & 0.78 \\
\hline 3.96 & 0.91 \\
\hline 4.34 & 0.76 \\
\hline 4.20 & 0.75 \\
\hline 4.23 & 0.78 \\
\hline 4.42 & 0.74 \\
\hline 4.12 & 0.81 \\
\hline 4.09 & 0.85 \\
\hline 4.20 & 0.81 \\
\hline
\end{tabular}


11) Implementing activities that secure student participation (individual, paired, group work, 4.05 performances, trips, observations, experiments, panels, etc.).

12) Asking questions that are appropriate for students' levels, that spark their interest in the subject and that make them think.

13) Presenting students with a variety of activities and opportunities for self-realization both inside and outside the classroom.

14) Being able to relate examples from coursework to daily life.

15) Interesting students in the course, encouraging them and ensuring that they continue.

16) Developing and implementing strategies for behavior management in a technologysupported learning environment.

17) Making effective use of verbal and body language (posture, expression, hand/arm movement, etc.) at a level appropriate for students.

18) Establishing and using an appropriate instrument of measurement to evaluate students.

19) Checking the reliability and validity of the instrument.

20) Analyzing data using ICT in student assessments.

21) Interpreting the results of measurements and providing students with feedback.

22) Listening to students and showing sensitivity in providing answers to their questions.

\section{SUBJECT MATTER KNOWLEDGE}

1) Installing the required software programs, regularly maintaining the system and updating/removing software as necessary.

2) Developing strategies to solve problems that have arisen or may arise in hardware/software used in the classroom and school environments.

3) Developing appropriate, effective methods (spreadsheet forms, macros, control methods, formulas and calculations) for automating common procedures.

4) Effectively using the Internet (telnet, internet browsers, file-transfer protocols, email groups, portals and search engines).

5) Introducing and making practical use of peripheral hardware (printers, scanners, cameras, etc.).

6) Developing strategies to assist learners in multi-platform design (text, tables, visuals, sound).

7) Using technological tools (discussion groups, chat rooms, forums, editing tools, and spreadsheet design programs) for communicating, problem-solving and presentation.

8) Developing teaching materials using databases, tabulation/calculation programs, hypermedia, web design, animation, graphics, desktop publishing and similar applications.

9) Using educational administrative systems or electronic grading programs for student registration.

10) Ensuring learners are able to share information using different platforms (email, posters, animation, and networks).

11) Evaluating, choosing and using basic educational software containing different tools/content.

12) Ensuring learners make use of ICT in support of their creative development. (Experimenting with different colors in an image, using an adventure game or simulation.) 
13) Having knowledge of and implementing legal and ethical (moral) regulations pertaining to data protection, information security, copyright and privacy as they relate to the use of ICT.

14) Cooperating with other teachers and leading them in the effective use of technology to increase their professional development.

15) Being a leader in terms of raising awareness and implementing procedures for equal access to technology in school and society.

16) Ensuring that students demonstrate positive social and moral behavior in using technology.

17) Making use of resources such as the Internet, professional organizations, conferences, journals and newspapers to keep up-to-date on educational technologies and practices.

18) Installing an appropriate network system and using this system to connect with other computers in the institution.

19) Designing and developing appropriate educational software in line with course content, learners' multiple intelligences and learning styles.

20) Designing new information systems, evaluating available systems and making recommendations regarding development (e.g., preparing and evaluating a web site, LMS, database, etc.)

21) Designing lessons involving appropriate technological tools that will cater to learners with special needs (mentally and physically handicapped).

22) Planning and implementing technology-based lessons that help learners to produce original products and develop their abilities to analyze, synthesize and criticize.

23) Using professional portals and databases such as ERIC for research, information access and knowledge sharing.

\begin{tabular}{l|l}
3.86 & 0.98 \\
4.33 & 0.84 \\
4.13 & 0.84 \\
4.38 & 0.75 \\
4.31 & 0.80 \\
3.82 & 1.22 \\
3.65 & 0.99 \\
3.66 & 1.04 \\
& \\
2.97 & 1.10 \\
3.90 & 1.10 \\
3.41 & 1.20 \\
\hline
\end{tabular}

\section{Biographies}

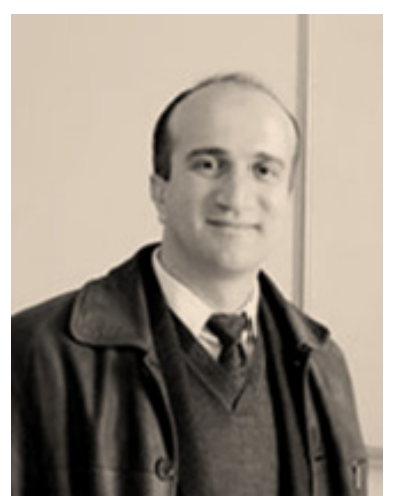

Recep Cakir, $\mathrm{PhD}$, is currently an assistant professor in the department of the Computer Education and Instructional Technology, at Amasya University, Amasya, Turkey. His main areas of research include; pre and in-service teacher technology training, teacher professional development, information and communication technology integration, web based education. He has published articles addressing different issues in information technologies and presented papers at several conferences.

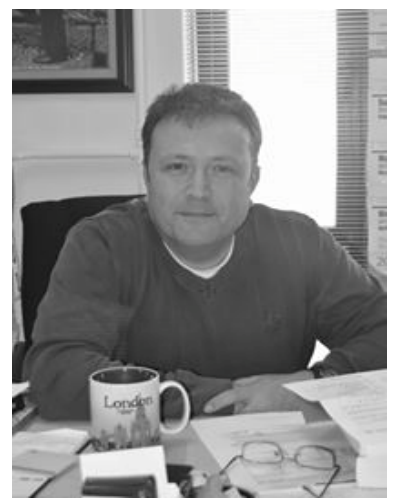

Soner Yildirim, $\mathrm{PhD}$, is currently a professor in the department of Computer Education and Instructional Technology, at Middle East Technical University, Ankara, Turkey. His main areas of research include; pre and in-service teacher technology training, web-based training, human performance technologies (EPSS), and reusable learning objects. He has published several articles in different international journals and presented at many conferences. Additionally, He has been serving as an editorial board member in several international journals. 